\title{
SPRINGER-VERLAG NEW YORK INC.
}

\section{Published by Springer-Verlag \\ Berlin - Heidelberg - New York: \\ Völkerrecht}

By Dr. jur. Dr. rer. pol.

Wilhelm Wengler

Professor of Law and Political

Affairs, Free University of Berlin

Membre de

l'institut de droit international

\section{Enzyklopädie}

der Rechts- und Staatswissenschaft

Originated by

F. von Liszt and W. Kunkel

Edited by

W. Kunkel, H. Peters, E. Preiser

Abt. Rechtswissenschaft

In German.

Vol. I, 930 pages, 8 vo., 1963

Vol. II: 931-1530 pages, 8 vo., 1963

Cloth U.S. $\$ 49.50$
Studies in International Law have become an international science in the sense that no one can restrict himself to the study of literature of his own country alone. Only a few scholars are in a position to peruse the enormous amount of data, treaties, decisions, and literature published throughout the world, and on the basis of all this are able to sketch a comprehensive picture of International Law, without giving disproportionate treatment to local aspects, and without being biased by national or ideological prejudices. The reviews of the standard work in German of the West Berlin Professor Wilhelm Wengler by leading exponents of International Law in Europe indicate that his book has avoided just those pitfalls. The book affords ample treatment of all the essential factors in general or regional International Law. Its comprehensive bibliography is designed to assist the reader in coming completely to grips with the whole range of material from several languages on each particular topic. A factor of equal importance is the manner in which Professor Wengler has placed many questions in a completely new light. As Professor Schwarzenberger (London) puts it, no discussion of particular questions of International Law can now validly be investigated without drawing on the advice of this work. Professors Schwarzenberger and Rousseau (Paris) each independently came to the conclusion that the book is an "epoch-making event in International Law."
SPINAER-VERLAG NEW YORK INC.

175 Fifth Avenne

Now York/N. X. 10010

\section{Please send me___ copies of Völkerrecht, $\$ 49.50$}

$\square$ Payment enclosed $\square$ Charge my account

(Add New York sales tax where necessary)

No postage charge on pre-paid orders

Please send me a leaflet and catalogs in this field

Name

Address

Or to your bookgeller

City State Zip No 


\section{The Procedural Aspects}

of International Law Series

Volume 4

\section{THE USE OF EXPERTS BY INTERNATIONAL TRIBUNALS Gillian White}

Conceived when the author, undertaking research for a large corporation engaged in international litigations involving the use of experts, could find no source book dealing with the problem, this down-to-earth study should stand for years as the essential work in this area of international law.

Chapter titles are: Expert Aid and the Nature of International Proceedings; Use of Experts by Municipal Courts; Competence of International Tribunals To Call Upon Experts-Express Competence: Competence of International Tribunals To Call Upon Experts-Implied Competence; Boundary Cases; Determination of Facts Which, if Established, Would Give Rise to International Responsibility; Questions of Valuation and Damages; Settling a Regime for the Future; the Role of Experts; Privileges and Immunities of Experts; Fees and Expenses.

Bibliography, appendixes, notes, table of cases.

$\$ 8.95$

Volume 3

\section{THE ROLE OF DOMESTIC COURTS IN THE INTERNATIONAL LEGAL ORDER \\ Richard A. Falk}

"This well-written book . . . discusses an already controversial subject in a highly provocative manner. Because Professor Falk's underlying thesis was adopted last Spring by the United States Supreme Court in Banco Nacional de Cuba v Sabbatino, his book is both timely and important. . . Professor Falk's reasoning has already made a considerable jurisprudential impact upon contemporary legal history."-Frank Griffith Dawson, New York City.

"Worthy of careful consideration by all students of International legal problems."-MichazL KATZ, Advocate to the Supreme Court of South Africa.

$\$ 6.50$

Volume 2

INTERNATIONAL CLAIMS: THEIR PREPARATION AND PRESENTATION

Richard B. Lillich and Gordon A. Christenson $\$ 6.50$

Volume 1

INTERNATIONAL CLAIMS: THEIR ADJUDICATION BY NATIONAL COMMISSIONS

Richard B. Lillich

Volume 5: (To be published in October)

THE PROTECTION OF FOREIGN INVESTMENT: SIX PROCEDURAL STUDIES

Richard B. Lillich

Bibliography, Appendixes, Index, Notes.

Syracuse University Press

Syracuse, New York 13210 


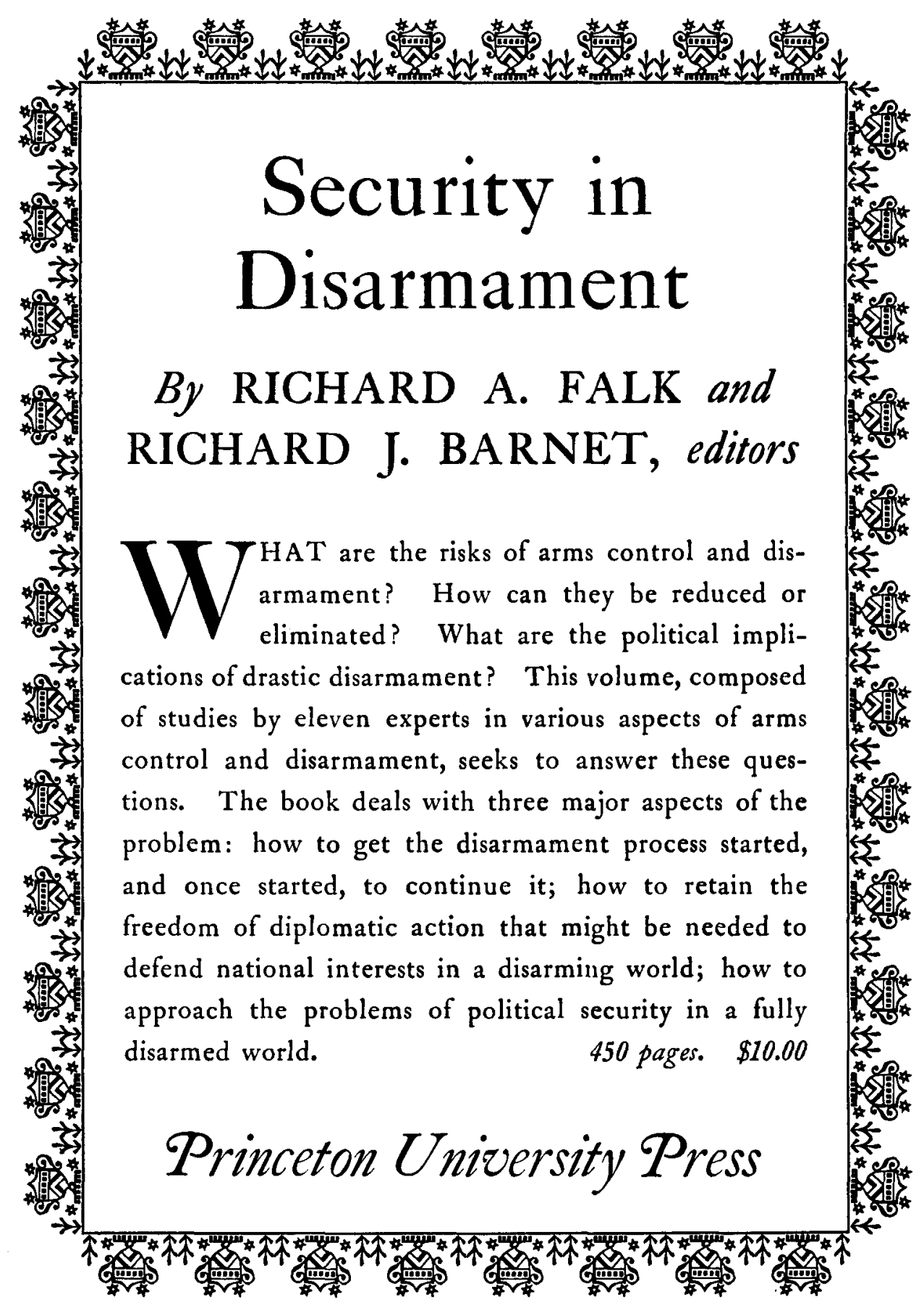




\section{AMERICAN SOCIETY OF INTERNATIONAL LAW}

\section{ANNOUNCEMENT OF NEW PUBLICATIONS}

\section{Legal Advisers and Foreign Affairs}

A report of a conference, sponsored by the Society, on the rôle of legal advisers in the conduct of foreign affairs, with descriptions of the organization of their offices in eleven governments. Edited by H. C. L. Merillat. Published for the Society by Oceana Publications, Inc., 40 Cedar Street, Dobbs Ferry, New York. 162 pp. $\$ 4.00$.

\section{Three Books on the Legal Context for Foreign Investment in Se-} lected Countries

A series of volumes analyzing the legal aspects of foreign private investment in selected countries, in the context of official policies and economic, political, and social trends. Written on research fellowships from the Society for studies in investment and economic development. All published by the University of North Carolina Press, Chapel Hill, North Carolina.

Foneign Enterprise in India: Laws and Policies. By Matthew J. Kust. $488 \mathrm{pp}$. and Index. $\$ 10.00$.

Foneign Enterprise in Colombia: Laws and Poliches. By Seymour W. Wurfel. $552 \mathrm{pp}$. and Index. $\$ 10.00$.

Foneign Enterprise in Nigerla: Laws and Policies. By Paul O. Proehl. To be published in September 1965. $\$ 7.50$.

\section{The Socialist Commonwealth of Nations: Organizations and} Institutions

A study of arrangements among Soviet-bloc countries for coordinating policies and settling disputes. Prepared under the Society's research program on movements toward federation and other forms of regional association. By Kazimierz Grzybowski. Published by the Yale University Press, New Haven, Connecticut. 287 pp. and Index. $\$ 7.50$.

\section{East African Unity Through Law}

A study of efforts by former British territories in East Africa to establish regional institutions to provide common services and to advance common interests. Another in the Society's series of studies in federalism. By Thomas M. Franck. Published by the Yale University Press, New Haven, Connecticut. $173 \mathrm{pp}$. and Index. $\$ 5.50$.

\section{Aden and the Federation of South Arabia The Constitution of the Congo}

Two separate papers written by J. Y. Brinton in the program on federalism. The first is a review of the development of the Federation of South Arabia and the accession of Aden; the second a translation into English, with Commentary, of the Congolese Constitution of August 1, 1964. Both published by the Society. \$2 each.

\section{Other Occasional Publications}

The Society has published the following reports; single copies are available upon request, without charge:

A Survey of the Teaching of International Law in Political Science Departments. Report of a survey carried out by the Society with the cooperation of the American Political Science Association. $115 \mathrm{pp}$.

Teaching of International Law and Related Courses in American Law Schools. Report of a conference organized by the Society in $1964.28 \mathrm{pp}$.

International Legal Studies: A Survey of Teaching in American Law Schools, 1963-64. Report of a survey carried out by the Society with the cooperation of the Association of American Law Schools. By Richard W. Edwards, Jr. $292 \mathrm{pp}$. 